\title{
Thermotherapy for Control of Fungal Pathogens in Propagative Rootstocks of Horseradish
}

\author{
Anas Eranthodi and Mohammad Babadoost ${ }^{\mathbf{1}}$ \\ Department of Crop Sciences, University of Illinois, N-533 Turner Hall, \\ Urbana, IL 61801
}

\section{Bernhard Trierweiler}

Max Rubner-Institut, Department of Safety and Quality of Fruit and Vegetables, Haid-und-Neu-Straße 9, Karlsruhe 76131, Germany

Additional index words. Armoracia rusticana, soil-borne pathogen, root rot, pathogen-free set

\begin{abstract}
This study was conducted to develop a reliable method for control of set-borne inoculum of Verticillium and Fusarium species that cause the internal discoloration of horseradish roots. Horseradish propagative root stocks (sets), 0.5 to $3.0 \mathrm{~cm}$ in diameter and 20 to $25 \mathrm{~cm}$ long, were treated by immersing them into water at 44, 45, 46, 47, 48, 49, and $50{ }^{\circ} \mathrm{C}$ for 10,20 , and $30 \mathrm{~min}$. Treated and untreated sets were cultured on acidified potato dextrose agar to determine the presence of the pathogens in the sets. Treatments at temperatures lower than $46^{\circ} \mathrm{C}$ did not control the set-borne inoculum of the pathogens. Treated and untreated sets were also planted in the greenhouse and fields to assess the effects of the thermotherapy on germination of the sets and vigor of the plants. Treatments at $48^{\circ} \mathrm{C}$ or greater either delayed or reduced set germination and reduced plant vigor. The most effective treatment for control of the set-borne pathogens without adverse effects on set germination or plant vigor was determined to be $47^{\circ} \mathrm{C}$ for $20 \mathrm{~min}$.
\end{abstract}

Horseradish (Armoracia rusticana Gaertn. Mey. \& Scherb.), a root crop in the Brassicaceae family, is cultivated for its white, pungent, fleshy root (Courter and Rhodes, 1969; Kadow and Anderson, 1940). Approximately half of the total commercial horseradish supply of the United States is grown in the Mississippi River Valley, near East St. Louis, IL (Babadoost et al., 2001; Rhodes, 1977). Eau Claire, WI, Clearbrook, MN, and Tule Lake, $\mathrm{CA}$, are the other three major horseradish production areas, each producing $\approx 15 \%$ of the total commercial horseradish in the United States (Babadoost et al., 2004). Horseradish also is grown on small scales in Connecticut, Massachusetts, Missouri, Mississippi, New Jersey, Ohio, Pennsylvania, and Washington states. Horseradish is a cash crop with the value of processed products exceeding $\$ 15,000$ per hectare (Babadoost, 2006).

Internal discoloration of horseradish roots occurs widely in the world and is the main limiting factor in horseradish production

Received for publication 21 Dec. 2009. Accepted for publication 22 Feb. 2010.

This research was supported in part by grants received from NC-IPM (CSREES Project No. AG MSU 61-425AA, CFDA No. 10.303) and the Illinois Department of Agriculture (IDOA-SA-07-33).

We thank the Association of Illinois Horseradish Growers and Keneth Traaseth, Huntsinger Farms Inc. in Wisconsin for providing horseradish sets and assisting in conducting the field studies.

${ }^{1}$ To whom reprint requests should be addressed; e-mail babadoos@illinois.edu.
(Babadoost et al., 2004; Eastburn and Chang, 1994; Gerber et al., 1983; Potschke, 1923; Stark, 1961). The disease has been known since 1920 in Europe (Potschke, 1923). Internal discoloration of horseradish roots in the United States was first described in 1931 in Michigan, where $20 \%$ of the yield was lost as a result of root infection (Boning, 1938). The discoloration of horseradish roots was reported in western Washington in 1937 by Heald et al. (1937) The disease was diagnosed in Wisconsin in 1973 (Mueller et al., 1982). Since the early 1980s, horseradish producers in Illinois have experienced substantial reductions in marketable yield of horseradish as a result of the internal discoloration of roots (Atibalentja and Eastburn, 1996; Babadoost, 2006; Eastburn and Chang, 1994; Gerber et al., 1983). Yield losses of up to $100 \%$, caused by the internal root discoloration, have frequently occurred in Illinois (Babadoost, 2006; Babadoost et al., 2004).

Potschke (1923) was the first to report a Verticillium species as the causal agent of the internal discoloration of horseradish. Heald et al. (1937) identified Verticillium dahliae in the internally discolored roots of horseradish in Washington. Eastburn and Chang (1994) reported $V$. dahliae as the primary causal agent of internal discoloration of horseradish roots in Illinois. Percich and Johnson (1990) and Babadoost et al. (2004) reported that internal discoloration of horseradish roots is a disease complex. Three fungal species, $V$. dahliae, $V$. longisporum, and Fusarium solani, were identified as the causal agents of the internal root discoloration (Babadoost et al., 2004).

Horseradish producers save their horseradish sets from their harvest to plant in the next season. Most of the sets that the producers save are apparently healthy (asymptomatic), but they are often infected with Verticillium and Fusarium spp. (Babadoost, 2006). Set transmission of these pathogens is important because infected set usually gives rise to severely discolored root, which is unmarketable (Babadoost, 2006; Babadoost et al., 2004). Thus, starting horseradish production from pathogen-free sets is essential for managing the internal discoloration of roots (Babadoost and Islam, 2002).

Pathogen-free sets of horseradish can be generated by tissue-culturing of horseradish leaves (Meyer and Milbrath, 1977; Norton et al., 2001; Uchanski et al., 2004). However, tissue-culture generation of horseradish sets with the existing technologies is not economically feasible (Aitken-Christie et al., 1995; Uchanski et al., 2007). In addition, the sets can become infected before used by producers because the final stage of tissue-culture set production involves increasing sets in the field at least for one full growing season. Thus, alternative methods of producing pathogenfree horseradish sets are needed.

Hot water treatments of seed and nursery stocks have been commonly used in plant disease management (Herder and Turechek, 2006; Lear and Lider, 1959; Nega et al., 2003; Walker, 1923; Wilson, 1974). As early as the end of the 19th century, hot water treatment was applied to control loose smut caused by Ustilago nuda in cereals (Jensen, 1888). In the 1920 s, hot water treatment of cabbage seed to control black leg disease was a standard method in the United States (Walker, 1923). McGee (1995) reported that hot water treatment was the only treatment available to eradicate deep-seated pathogens in the seed without significant losses of seed germination or plant vigor. Lear and Lider (1959) recommended eradication of rootknot nematodes from grapevine rootings by hot water treatment. Herder and Turechek (2006) reported eradication of Xanthomonas fragariae in strawberry nursery stock by hot water treatment. Neri et al. (2009) reported eradication of Neofabraea alba in apple by treating fruits in water at $50{ }^{\circ} \mathrm{C}$.

This study was conducted to determine the effectiveness of hot water treatment of horseradish sets to control set-borne fungal pathogens without negatively affecting set germination or plant vigor.

\section{Materials and Methods}

Hot water treatment of sets. A Blue M electrical laboratory water bath (Model MW1120A-1; BLUE M Electrical Company, Blue Island, IL), with $30,000-\mathrm{cm}^{3}$ capacity, was used for hot water treatment of the horseradish sets. The water bath was filled with water to $80 \%$ of its capacity and the temperature of water was set to the appropriate temperature. The water temperature was 
monitored by using a thermometer. Each time, 20 horseradish sets were placed in a perforated stainless steel basket and immersed into the water. After re-establishing the desired temperature, the sets were incubated for the scheduled time and then removed from the bath and dried on blotters at room temperature $\left(22^{\circ} \mathrm{C}\right)$.

Set culturing. Set culturing was conducted in the laboratory to evaluate presence of fungi in the sets. All horseradish sets for culturing were provided by commercial growers in Illinois. Three experiments with different horseradish cultivars were conducted. In all three experiments, 30 sets from each treatment (temperature-time) were cultured.

The first experiment was conducted using horseradish cultivar 1590 without any visible internal discoloration of sets (asymptomatic sets). Sets 1.5 to $2.5 \mathrm{~cm}$ in diameter $\times 25 \mathrm{~cm}$ long were treated in water at temperatures of $44,46,48$, and $50^{\circ} \mathrm{C}$, each for 10 and $30 \mathrm{~min}$ (Table 1).

In the second experiment, sets of horseradish cultivars 1573 and 1722 were included (Table 2). The sets of cultivar 1573 were asymptomatic. In cultivar 1722, asymptomatic and internally discolored sets were tested. Discoloration severity of the sets of cultivar 1722 ranged from $1 \%$ to $10 \%$ at the cross-section. In both cultivars, sets measuring 1.5 to $2.5 \mathrm{~cm}$ in diameter $\times 25 \mathrm{~cm}$ long were treated in water at temperatures of 46 , 47 , and $48^{\circ} \mathrm{C}$, each for 10,20 , and $30 \mathrm{~min}$.

In the third experiment, sets of cultivar Victor-7, exhibiting the internal discoloration, were used. Severity of the discoloration ranged from $10 \%$ to $30 \%$ at the cross-section. Sets with two sizes of 0.5 to $1.5 \mathrm{~cm}$ in diameter $\times 25 \mathrm{~cm}$ long and 1.5 to $3.0 \mathrm{~cm}$ in diameter $\times$ $25 \mathrm{~cm}$ long (Table 3 ) were treated in water at $44{ }^{\circ} \mathrm{C}$ for $30 \mathrm{~min}$ and $45,46,47,48$, and $49^{\circ} \mathrm{C}$ each for 10, 20, and $30 \mathrm{~min}$.

All of the sets from the first and the second experiments and half of the sets from the third experiment were cultured within 2 weeks after heat treatment. Another half of the sets from the third experiment were stored at $4{ }^{\circ} \mathrm{C}$ after

Table 1. Sets of horseradish cultivar 1590 with fungal colonies following set treatment in hot water.

\begin{tabular}{lcc}
\hline \multicolumn{2}{c}{ Treatment } & $\begin{array}{c}\text { Sets with fungal } \\
\text { colonies }(\%)^{\mathrm{z}}\end{array}$ \\
\hline Temperature $\left({ }^{\circ} \mathrm{C}\right)$ & Time $(\mathrm{min})$ & $6.7 \mathrm{~b}^{\mathrm{y}}$ \\
44 & 10 & $6.0 \mathrm{~b}$ \\
46 & 30 & $3.3 \mathrm{~b}$ \\
46 & 10 & $4.0 \mathrm{~b}$ \\
48 & 30 & $3.3 \mathrm{~b}$ \\
48 & 10 & $2.7 \mathrm{~b}$ \\
50 & 30 & $2.7 \mathrm{~b}$ \\
50 & 10 & $1.3 \mathrm{~b}$ \\
Untreated control & 30 & $13.3 \mathrm{a}$ \\
LSD $(P=0.05)$ & & 6.2 \\
\hline
\end{tabular}

${ }^{\mathrm{z}}$ Original sets were asymptomatic. Sets were cultured on acidified potato dextrose agar. Each value represents the mean of 30 sets.

'Values followed by the same letter are not significantly different according to Fisher's protected least significant difference (LSD). the treatment and cultured after 3 months from the date of the treatment. The sets were first surface-sterilized and then cultured on acidified potato dextrose agar (A-PDA) in petri plates. A-PDA was prepared by adding $4 \mathrm{~mL}$ of $25 \%$ lactic acid to each liter of the culture medium before pouring into petri plates.

Sets were surface-disinfected using the method described by Babadoost et al. (2004). Five segments (each $\approx 0.5 \mathrm{~cm}$ thick) from each surface-disinfected set were placed onto A-PDA in one petri plate. The culture plates were incubated at 20 to $24^{\circ} \mathrm{C}$ with 12 -h light/ 12-h darkness. Cultured segments were ex-

Table 2. Sets of horseradish cultivars 1573 and 1722 with fungal colonies after set treatment in hot water.

\begin{tabular}{|c|c|c|c|}
\hline \multicolumn{2}{|l|}{ Treatment } & \multicolumn{2}{|c|}{$\begin{array}{l}\text { Sets with fungal } \\
\text { colonies }(\%)^{\mathrm{z}}\end{array}$} \\
\hline Temperature $\left({ }^{\circ} \mathrm{C}\right)$ & $\begin{array}{l}\text { Time } \\
(\mathrm{min})\end{array}$ & $\begin{array}{c}\text { Cultivar } \\
1573^{\mathrm{y}}\end{array}$ & $\begin{array}{l}\text { Cultivar } \\
1722^{\mathrm{x}}\end{array}$ \\
\hline$\overline{46}$ & 10 & $18.8 \mathrm{ab}^{\mathrm{w}}$ & $6.3 \mathrm{~b}^{\mathrm{w}}$ \\
\hline 46 & 20 & $2.5 \mathrm{c}$ & $8.8 \mathrm{~b}$ \\
\hline 46 & 30 & $12.5 \mathrm{bc}$ & $3.8 \mathrm{~b}$ \\
\hline 47 & 10 & $15.0 \mathrm{a}-\mathrm{c}$ & $11.3 \mathrm{~b}$ \\
\hline 47 & 20 & $7.5 \mathrm{bc}$ & $6.5 \mathrm{~b}$ \\
\hline 47 & 30 & $3.8 \mathrm{c}$ & $6.3 \mathrm{~b}$ \\
\hline 48 & 10 & $5.0 \mathrm{c}$ & $3.8 \mathrm{~b}$ \\
\hline 48 & 20 & $10.0 \mathrm{bc}$ & $2.5 \mathrm{~b}$ \\
\hline 48 & 30 & $3.8 \mathrm{c}$ & $0.0 \mathrm{~b}$ \\
\hline Untreated control & & $26.3 \mathrm{a}$ & $37.5 \mathrm{a}$ \\
\hline $\operatorname{LSD}_{(P=0.05)}$ & & 13.6 & 15.1 \\
\hline
\end{tabular}

${ }^{\mathrm{z}}$ Sets were cultured on acidified potato dextrose agar. Each value represents the mean of 30 sets.

${ }^{y}$ Sets of cultivar 1573 were asymptomatic.

${ }^{\mathrm{x}}$ Sets of cultivar 1722 were internally discolored; discoloration severity ranged from $1 \%$ to $10 \%$ at the cross-section of the sets.

${ }^{\text {w}}$ Values followed by the same letter within each column are not significantly different according to Fisher's protected least significant difference (LSD).

Table 3. Different size of sets of horseradish cultivar Victor-7 with fungal colonies detected $14 \mathrm{~d}$ and 3 months after treatment in hot water.

\begin{tabular}{|c|c|c|c|c|c|}
\hline \multirow{2}{*}{\multicolumn{2}{|c|}{ Treatment }} & \multicolumn{4}{|c|}{ Sets with fungal colonies $(\%)^{z}$} \\
\hline & & \multicolumn{2}{|c|}{$\begin{array}{c}0.5-1.5 \mathrm{~cm} \text { diam } \times 25 \mathrm{~cm} \\
\text { long sets }\end{array}$} & \multicolumn{2}{|c|}{$\begin{array}{c}1.5-3.0 \mathrm{~cm} \mathrm{diam} \times 25 \mathrm{~cm} \\
\text { long sets }\end{array}$} \\
\hline Temperature $\left({ }^{\circ} \mathrm{C}\right)$ & $\begin{array}{l}\text { Time } \\
(\mathrm{min})\end{array}$ & $\begin{array}{l}14 \mathrm{~d}_{\text {after heat }} \\
\text { treatment }^{\mathrm{y}}\end{array}$ & $\begin{array}{c}3 \text { months after heat } \\
\text { treatment }^{\mathrm{y}}\end{array}$ & $\begin{array}{l}14 \mathrm{~d} \text { after heat } \\
\text { treatment }^{\mathrm{y}}\end{array}$ & $\begin{array}{l}3 \text { months after } \\
\text { heat treatment }{ }^{\mathrm{y}}\end{array}$ \\
\hline$\overline{44}$ & 30 & $13.8 \mathrm{~b}-\mathrm{f}^{\mathrm{x}}$ & $12.5 \mathrm{bc}^{\mathrm{x}}$ & $26.7 b-d^{x}$ & $21.7 \mathrm{ab}^{\mathrm{x}}$ \\
\hline 45 & 10 & $23.8 \mathrm{a}-\mathrm{c}$ & $10.0 \mathrm{bc}$ & $23.3 \mathrm{~b}-\mathrm{e}$ & $20.0 \mathrm{a}-\mathrm{c}$ \\
\hline 45 & 20 & $10.0 \mathrm{c}-\mathrm{f}$ & $12.5 \mathrm{bc}$ & $16.7 \mathrm{c}-\mathrm{f}$ & $3.3 \mathrm{~d}$ \\
\hline 45 & 30 & $13.8 \mathrm{~b}-\mathrm{f}$ & $8.8 \mathrm{bc}$ & $5.0 \mathrm{ef}$ & $16.7 \mathrm{a}-\mathrm{d}$ \\
\hline 46 & 10 & $26.3 \mathrm{a}$ & $16.0 \mathrm{~b}$ & $53.3 \mathrm{a}$ & $11.7 \mathrm{a}-\mathrm{d}$ \\
\hline 46 & 20 & $13.8 \mathrm{~b}-\mathrm{f}$ & $7.5 \mathrm{bc}$ & $26.7 \mathrm{~b}-\mathrm{d}$ & $5.0 \mathrm{~cd}$ \\
\hline 46 & 30 & $7.5 \mathrm{ef}$ & $8.8 \mathrm{bc}$ & $15.0 \mathrm{c}-\mathrm{f}$ & $6.7 \mathrm{~b}-\mathrm{d}$ \\
\hline 47 & 10 & 17.5 be & $10.0 \mathrm{bc}$ & $10.0 \mathrm{~d}-\mathrm{f}$ & $5.0 \mathrm{~cd}$ \\
\hline 47 & 20 & $7.5 \mathrm{ef}$ & $2.5 \mathrm{c}$ & $13.0 \mathrm{~d}-\mathrm{f}$ & $6.7 \mathrm{~b}-\mathrm{d}$ \\
\hline 47 & 30 & $7.5 \mathrm{ef}$ & $5.0 \mathrm{bc}$ & $5.0 \mathrm{ef}$ & $3.3 \mathrm{~d}$ \\
\hline 48 & 10 & $10.0 \mathrm{c}-\mathrm{f}$ & $15.0 \mathrm{bc}$ & $20.0 \mathrm{~b}-\mathrm{e}$ & $6.7 \mathrm{~b}-\mathrm{d}$ \\
\hline 48 & 20 & $6.3 \mathrm{ef}$ & $6.3 \mathrm{bc}$ & $11.7 \mathrm{~d}-\mathrm{f}$ & $6.7 b-d$ \\
\hline 48 & 30 & $0.0 \mathrm{f}$ & $7.5 \mathrm{bc}$ & $0.0 \mathrm{f}$ & $8.3 \mathrm{~b}-\mathrm{d}$ \\
\hline 49 & 10 & $1.3 \mathrm{f}$ & $2.5 \mathrm{c}$ & $3.3 \mathrm{f}$ & $5.0 \mathrm{~cd}$ \\
\hline 49 & 20 & $0.0 \mathrm{f}$ & $10.0 \mathrm{bc}$ & $1.7 \mathrm{f}$ & $3.3 \mathrm{~d}$ \\
\hline 49 & 30 & $1.3 \mathrm{f}$ & $6.3 \mathrm{bc}$ & $1.7 \mathrm{f}$ & $13.3 \mathrm{~b}-\mathrm{d}$ \\
\hline Untreated control & & $22.5 \mathrm{a}-\mathrm{d}$ & $35.0 \mathrm{a}$ & $31.7 \mathrm{bc}$ & $31.7 \mathrm{a}$ \\
\hline $\operatorname{LSD}_{(P=0.05)}$ & & 15.3 & 13.1 & 18.4 & 15.7 \\
\hline
\end{tabular}

${ }^{\mathrm{z}}$ Each value represents the mean of 30 sets.

${ }^{y}$ Sets were cultured on acidified potato dextrose agar.

'Values followed by the same letter within each column are not significantly different according to Fisher's protected least significant difference (LSD). amined for fungal growth 5,10 , and $15 \mathrm{~d}$ after plating. Plugs $2 \mathrm{~mm}$ in diameter from the edge of each growing fungal colony from the segments were transferred onto PDA in petri plates, the plates were incubated at 20 to $24{ }^{\circ} \mathrm{C}$ for up to $14 \mathrm{~d}$, and then the fungus was teristics.

Root infection-greenhouse studies. Two experiments were conducted in a greenhouse to determine the effectiveness of thermotherapy on eliminating set-borne fungal pathogens. In the first experiment, two cultivars, 1573 and Big Top Western (BTW), provided by the commercial producers, were used. The sets used in this experiment were internally discolored; severity of the discoloration at the cross-sections ranged from $5 \%$ to $30 \%$. Sets with no obvious discoloration (asymptomdiameter and $20 \mathrm{~cm}$ long, were treated in water with temperatures $47{ }^{\circ} \mathrm{C}$ for $20 \mathrm{~min}$ (Table 4). Nonheat-treated sets were included in the experiment. Treated and nontreated sets were planted in linear plastic pots $(27 \mathrm{~cm} \times 13$ $\mathrm{cm} \times 13 \mathrm{~cm}$ ) filled with a steam-pasteurized soil:peat:perlite mix $(2: 1: 1)$. The sets were planted $7 \mathrm{~cm}$ deep in the mix on 6 Aug. 2008 (one set per pot) and the pots were placed on greenhouse benches at temperatures ranging from 18 to $26{ }^{\circ} \mathrm{C}$. The pots were arranged in a split-plot design. Cultivars were assigned randomly to main plots and treatments (heattreated and nonheat-treated) to subplots. Four replications of main plots and subplots were arranged in a completely randomized block design. Each replication included nine pots (nine plants). The plants were harvested on 24 Nov. 2008 and roots were washed and evaluated (naked eye observation) for incidence and severity of the internal root discoloration at the identified based on its morphological characatic) were included. The sets, 1.5 to $2.5 \mathrm{~cm}$ in 
cross-section of eat root at one third from the top of the main root (original set).

In the second experiment, cultivars Czechoslovakia and Eastern, provided by the commercial producers, were used. Sets with four different groups of internal discoloration severity were included in this study, which were: 1) sets with no obvious discoloration; 2) sets with $1 \%$ to $10 \%$ discoloration; 3 ) sets with $11 \%$ to $50 \%$ discoloration; and 4 ) sets with greater than $50 \%$ discoloration (Table 5). The sets, 1.5 to $2.5 \mathrm{~cm}$ in diameter and $20 \mathrm{~cm}$ long, were either heat-treated in water at $47^{\circ} \mathrm{C}$ for $20 \mathrm{~min}$ or not heat-treated. As a result, eight treatments (four heat-treated and four untreated) for each cultivar were included. Treated and untreated sets were planted in linear plastic pots $(27 \mathrm{~cm} \times 13 \mathrm{~cm} \times 13 \mathrm{~cm})$ filled with a steam-pasteurized soil:peat:perlite mix $(2: 1: 1)$ as described in the previous experiment. The pots were arranged in a splitplot design. Cultivars were assigned randomly to main plots and treatments (heat discoloration severity) to subplots. Four replications of main plots and subplots were arranged in a completely randomized block design. Each replication included four pots (four plants). The sets were planted on 25 Nov. 2008 and plants were harvested on 25 Mar. 2009. Internal root discoloration of the roots was evaluated as described in the previous experiment.

Set germination and plant vigorgreenhouse and field studies. One experiment in the greenhouse and five experiments in commercial fields were conducted in the greenhouse to determine the effects of thermotherapy on set germination and plant vigor. Four horseradish cultivars, including '15K', '1573', '1722', and BTW, provided by the commercial producers, were used in these studies. All of the sets tested were asymptomatic, representing the sets planted by the commercial producers.

Two cultivars, $15 \mathrm{~K}$ and 1573 , were included in the greenhouse experiment, which was conducted in 2007. Sets, 1.5 to $2.5 \mathrm{~cm}$ in diameter and $20 \mathrm{~cm}$ long, were selected for heat treatment. The sets were treated in water with temperatures of $46,47,48,49$, and $50^{\circ} \mathrm{C}$, each for three different time periods of 10, 20, and $30 \mathrm{~min}$ (Table 6). Untreated sets were included for each cultivar. The sets were planted in $25 \mathrm{~cm} \times 25 \mathrm{~cm} \times 5-\mathrm{cm}$ flats filled with a steam-pasteurized soil:peat:perlite mix $(2: 1: 1)$. Five sets were planted in each flat on 10 Jan. 2007 and the flats were placed on benches of the greenhouse at 18 to $24{ }^{\circ} \mathrm{C}$. The flats were arranged in a split-plot design. Cultivars were assigned randomly to main plots and treatments (heat treatment time) to subplots. Three replications (one flat with five sets each) for each cultivar-temperaturetreatment time combination were included. The data on set germination, vigor of foliage growth, and foliage weight were recorded for each flat on 15 Feb. 2007. The vigor of plant foliage growth was assessed on a scale of 0 to 4 , in which $0=$ no foliage growth (no set germination); 1 = foliage of the plant being one third of normally growing plants; $2=$

Table 4. Incidence and severity of internal root discoloration of horseradish plants grown from hot watertreated and untreated infected sets in the greenhouse in 2008.

\begin{tabular}{|c|c|c|c|}
\hline \multirow[b]{2}{*}{ Cultivar } & \multirow[b]{2}{*}{ Treatment } & \multicolumn{2}{|c|}{ Internal root discoloration } \\
\hline & & Incidence $(\%)^{\mathrm{z}}$ & Severity $(\%)$ mean (range) $)^{y}$ \\
\hline \multirow[t]{3}{*}{$1573^{x}$} & Hot water $\left(47^{\circ} \mathrm{C}, 20 \mathrm{~min}\right)$ & $8.33 \mathrm{~b}^{\mathrm{w}}$ & $0.42 \mathrm{~b}(0-5)$ \\
\hline & Untreated control & $83.33 \mathrm{a}$ & 7.22 a $(0-40)$ \\
\hline & $\left.\operatorname{LSD}_{(P}=0.05\right)$ & 15.64 & 2.91 \\
\hline \multirow[t]{3}{*}{ BTW $^{x}$} & Hot water $\left(47^{\circ} \mathrm{C}, 20 \mathrm{~min}\right)$ & $0.00 \mathrm{~b}$ & $0.00 \mathrm{~b}(0)$ \\
\hline & Untreated control & $66.67 \mathrm{a}$ & 4.17 a $(0-15)$ \\
\hline & $\operatorname{LSD}_{(P=0.05)}$ & 15.89 & 1.16 \\
\hline
\end{tabular}

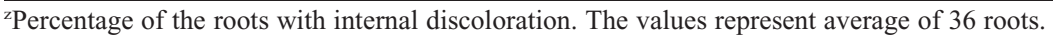
${ }^{y}$ Percentage of root surface discolored at the cross-section.

${ }^{x}$ All sets were internally discolored. Severity of the discoloration ranged from $5 \%$ to $30 \%$.

${ }^{w}$ Values followed by the same letter within each column and for each cultivar are not significantly different according to Fisher's protected least significant difference (LSD).

Table 5. Incidence and severity of internal root discoloration of horseradish plants grown from hot watertreated and untreated infected sets in the greenhouse in 2009.

\begin{tabular}{|c|c|c|c|c|}
\hline \multirow[b]{2}{*}{ Cultivar } & \multirow[b]{2}{*}{ Treatment } & \multirow{2}{*}{$\begin{array}{l}\text { Severity of set } \\
\text { discoloration }\end{array}$} & \multicolumn{2}{|c|}{ Internal root discoloration } \\
\hline & & & Incidence $(\%)^{y}$ & Severity $(\%)^{x}$ \\
\hline \multirow[t]{9}{*}{ Czechoslovakia } & Hot water $\left(47^{\circ} \mathrm{C}, 20 \mathrm{~min}\right)$ & None & $0.00 \mathrm{~d}^{\mathrm{x}}$ & $0.00 \mathrm{~d}$ \\
\hline & & Low & $12.50 \mathrm{~cd}$ & $0.62 \mathrm{~d}$ \\
\hline & & Medium & $12.50 \mathrm{~cd}$ & $0.62 \mathrm{~d}$ \\
\hline & & High & $6.25 \mathrm{~cd}$ & $0.31 \mathrm{~d}$ \\
\hline & Untreated control & None & $25.00 \mathrm{c}$ & $1.25 \mathrm{~d}$ \\
\hline & & Low & $62.50 \mathrm{~b}$ & $3.12 \mathrm{c}$ \\
\hline & & Medium & $75.00 \mathrm{~b}$ & $5.00 \mathrm{~b}$ \\
\hline & & High & $100 \mathrm{a}$ & $6.87 \mathrm{a}$ \\
\hline & $\left.\operatorname{LSD}_{(P}=0.05\right)$ & & 24.07 & 1.53 \\
\hline \multirow[t]{9}{*}{ Eastern } & Hot water $\left(47^{\circ} \mathrm{C}, 20 \mathrm{~min}\right)$ & None & $0.00 \mathrm{c}$ & $0.00 \mathrm{~d}$ \\
\hline & & Low & $0.00 \mathrm{c}$ & $0.00 \mathrm{~d}$ \\
\hline & & Medium & $0.00 \mathrm{c}$ & $0.00 \mathrm{~d}$ \\
\hline & & High & $12.50 \mathrm{c}$ & $1.25 \mathrm{bcd}$ \\
\hline & Untreated control & None & $12.50 \mathrm{c}$ & $0.62 \mathrm{~cd}$ \\
\hline & & Low & $50.00 \mathrm{~b}$ & $2.50 \mathrm{~b}$ \\
\hline & & Medium & $37.50 \mathrm{~b}$ & $1.87 \mathrm{bc}$ \\
\hline & & High & $75.00 \mathrm{a}$ & $4.37 \mathrm{a}$ \\
\hline & $\operatorname{LSD}_{(P=0.05)}$ & & 24.12 & 1.36 \\
\hline
\end{tabular}

${ }^{\mathrm{z}}$ None $=$ no discoloration at the cross section of the set; low $=1 \%$ to $10 \%$; medium $=11 \%$ to $50 \%$; and high $=$ greater than $50 \%$ discoloration of the sets at the cross-section.

${ }^{y}$ Percentage of the root with internal discoloration. The values represent average of 16 roots.

xPercentage of root surface discolored at the cross-section.

"Values followed by the same letter within each column and for each cultivar are not significantly different according to Fisher's protected least significant difference (LSD).

foliage of the plant being two thirds of normally growing plants; and $4=$ foliage of the plant as the same as the normally growing plants. Normally growing plants were the plants grown from nondiscolored and nonheat-treated plants in each cultivar. The foliage weight was the weight of freshly harvested leaves $37 \mathrm{~d}$ after planting.

The field experiments were conducted during 2007-2009. In 2007, four cultivars, $15 \mathrm{~K}, 1573,1722$, and BTW, were included in the field experiments. The asymptomatic sets ( 1.5 to $2.5 \mathrm{~cm}$ in diameter $\times 25 \mathrm{~cm}$ long) were treated in water at 46,47 , and $48^{\circ} \mathrm{C}$, each for three time periods of 10,20 , and $30 \mathrm{~min}$ (Table 7). The experiment was conducted in a commercial field near Collinsville, IL, with a silt clay loam soil. The sets were planted on 18 May. The experiment was performed using a split-plot design of randomized complete blocks with four replications (10 sets per replication). The space between adjacent sets within the row was $60 \mathrm{~cm}$ and the space between the adjacent rows was $90 \mathrm{~cm}$. The data on set germination and foliage vigor were recorded on 18 June, 18 July, and 20 Aug.

During 2008 and 2009, field experiments were conducted in commercial fields at Col- linsville, IL, and Eau Claire, WI. Cultivars 1573 and BTW were included in the experiments at Collinsville, IL. Only cultivar BTW was included in the experiments at Eau Claire, WI (Table 8). The sets (1.5 to 2.5 $\mathrm{cm}$ diameter $\times 25 \mathrm{~cm}$ long) were treated in water at $47{ }^{\circ} \mathrm{C}$ for $20 \mathrm{~min}$.

The experiments in Illinois were performed using a split-plot design of randomized complete blocks with four replications (10 sets per replication) as previously described. The space between adjacent sets within the row was $60 \mathrm{~cm}$ and the space between the adjacent rows was $90 \mathrm{~cm}$. In 2008, the sets were planted on 29 May. The data on set germination and foliage vigor were recorded on 13 June, 10 July, 1 Aug., 11 Sept., and 2 Oct. Plants were harvested on 2 Oct. and roots were evaluated for severity of internal root discoloration at the crosssection one third from top of the main root (original set). In 2009, the sets were planted on 1 June and set germination and foliage vigor were assessed on 12 July, 7 Aug., 8 Sept., and 5 Oct. Plants were harvested on 13 Nov. and roots were assessed for severity of internal discoloration as described previously.

The experiments in Wisconsin were performed using a randomized complete block 
Table 6. Set germination and vigor of foliage growth of horseradish plants in the greenhouse after set treatment in hot water.

\begin{tabular}{|c|c|c|c|c|c|c|c|}
\hline \multicolumn{2}{|c|}{ Treatment } & \multicolumn{3}{|c|}{ Cultivar $15 \mathrm{~K}^{\mathrm{z}}$} & \multicolumn{3}{|c|}{ Cultivar $1573^{z}$} \\
\hline Temperature $\left({ }^{\circ} \mathrm{C}\right)$ & Time $(\min )$ & Set germination $(\%)$ & Foliage vigor $^{\mathrm{y}}$ & Foliage wt $(\mathrm{g})^{\mathrm{x}}$ & Set germination $(\%)$ & Foliage vigor $^{\mathrm{y}}$ & Foliage wt $(\mathrm{g})^{\mathrm{x}}$ \\
\hline$\overline{46}$ & 10 & $100 a^{w}$ & $3.47 \mathrm{a}$ & $19.17 \mathrm{ab}$ & $100 \mathrm{a}$ & $3.07 \mathrm{a}-\mathrm{d}$ & $16.63 \mathrm{ab}$ \\
\hline 46 & 20 & $100 \mathrm{a}$ & $3.40 \mathrm{ab}$ & $19.83 \mathrm{ab}$ & $100 \mathrm{a}$ & $3.33 \mathrm{ab}$ & $19.60 \mathrm{ab}$ \\
\hline 46 & 30 & $100 \mathrm{a}$ & $3.53 \mathrm{a}$ & $23.43 \mathrm{a}$ & $100 \mathrm{a}$ & $3.20 \mathrm{a}-\mathrm{c}$ & $17.27 \mathrm{ab}$ \\
\hline 47 & 10 & $100 \mathrm{a}$ & $3.20 \mathrm{a}-\mathrm{d}$ & $16.67 \mathrm{~b}$ & $100 \mathrm{a}$ & $3.33 \mathrm{ab}$ & $20.63 \mathrm{ab}$ \\
\hline 47 & 20 & $100 \mathrm{a}$ & $3.40 \mathrm{ab}$ & $18.57 \mathrm{ab}$ & $100 \mathrm{a}$ & $3.27 \mathrm{a}-\mathrm{c}$ & $21.77 \mathrm{a}$ \\
\hline 47 & 30 & $100 \mathrm{a}$ & $3.07 \mathrm{a}-\mathrm{d}$ & $16.97 \mathrm{~b}$ & $100 \mathrm{a}$ & $3.20 \mathrm{a}-\mathrm{c}$ & $20.27 \mathrm{ab}$ \\
\hline 48 & 10 & $100 \mathrm{a}$ & $2.93 \mathrm{a}-\mathrm{d}$ & $16.33 \mathrm{~b}$ & $100 \mathrm{a}$ & $3.27 \mathrm{a}-\mathrm{c}$ & $18.70 \mathrm{ab}$ \\
\hline 48 & 20 & $93.0 \mathrm{a}$ & $3.07 \mathrm{a}-\mathrm{d}$ & $18.46 \mathrm{ab}$ & $100 \mathrm{a}$ & $3.07 \mathrm{a}-\mathrm{d}$ & $19.77 \mathrm{ab}$ \\
\hline 48 & 30 & $100 \mathrm{a}$ & $3.20 \mathrm{a}-\mathrm{d}$ & $18.87 \mathrm{ab}$ & $100 \mathrm{a}$ & $3.40 \mathrm{a}$ & $29.77 \mathrm{a}$ \\
\hline 49 & 10 & $100 \mathrm{a}$ & $3.07 \mathrm{a}-\mathrm{d}$ & $16.37 \mathrm{~b}$ & $100 \mathrm{a}$ & $3.07 \mathrm{a}-\mathrm{d}$ & $21.90 \mathrm{a}$ \\
\hline 49 & 20 & $100 \mathrm{a}$ & $3.27 \mathrm{a}-\mathrm{c}$ & $18.23 \mathrm{ab}$ & $100 \mathrm{a}$ & $3.00 \mathrm{a}-\mathrm{d}$ & $18.87 \mathrm{ab}$ \\
\hline 49 & 30 & $100 \mathrm{a}$ & $2.73 \mathrm{~cd}$ & $15.97 \mathrm{~b}$ & $100 \mathrm{a}$ & $2.93 \mathrm{a}-\mathrm{d}$ & $17.53 \mathrm{ab}$ \\
\hline 50 & 10 & $100 \mathrm{a}$ & $3.47 \mathrm{a}$ & $20.83 \mathrm{ab}$ & $100 \mathrm{a}$ & $3.00 \mathrm{a}-\mathrm{d}$ & $17.53 \mathrm{ab}$ \\
\hline 50 & 20 & $93.0 \mathrm{a}$ & $2.62 \mathrm{~d}$ & $18.50 \mathrm{ab}$ & $87.0 \mathrm{a}$ & $2.85 \mathrm{~b}-\mathrm{d}$ & $18.77 \mathrm{ab}$ \\
\hline 50 & 30 & $80.0 \mathrm{~b}$ & $2.79 \mathrm{~b}-\mathrm{d}$ & $18.21 \mathrm{ab}$ & $73.0 \mathrm{~b}$ & $2.82 \mathrm{~cd}$ & $16.14 \mathrm{~b}$ \\
\hline Untreated control & & $100 \mathrm{a}$ & $2.73 \mathrm{~cd}$ & $14.40 \mathrm{~b}$ & $100 \mathrm{a}$ & $2.67 \mathrm{~d}$ & $16.00 \mathrm{~b}$ \\
\hline$\underline{\operatorname{LSD}}(P=0.05)$ & & 10.60 & 0.64 & 6.45 & 13.50 & 0.50 & 5.61 \\
\hline
\end{tabular}

${ }^{\mathrm{z} S e t}$ germination, vigor of foliage growth, and foliage weight were assessed $35 \mathrm{~d}$ after planting sets. Each value represents the mean of 15 plants.

${ }^{y}$ Vigor of foliage growth was assessed on a scale of 0 to 4 in each plot, 0 being no plant growth and 4 the highest foliage vigor.

${ }^{\mathrm{x}}$ Weight of freshly harvested leaves $35 \mathrm{~d}$ after planting sets.

"Values followed by the same letter within each column are not significantly different according to Fisher's protected least significant difference (LSD).

Table 7. Set germination and vigor of foliage growth of horseradish plants in the field in Illinois after set treatment in hot water in 2007.

\begin{tabular}{|c|c|c|c|c|c|c|c|c|c|}
\hline \multicolumn{2}{|l|}{ Treatment } & \multicolumn{2}{|c|}{ Cultivar $15 \mathrm{~K}$} & \multicolumn{2}{|c|}{ Cultivar 1573} & \multicolumn{2}{|c|}{ Cultivar 1722} & \multicolumn{2}{|c|}{ Cultivar BTW } \\
\hline Temperature $\left({ }^{\circ} \mathrm{C}\right)$ & $\begin{array}{l}\text { Time } \\
(\mathrm{min})\end{array}$ & $\begin{array}{l}\text { Set germination } \\
(\%)^{z}\end{array}$ & $\begin{array}{l}\text { Foliage } \\
\text { vigor }^{\mathrm{y}}\end{array}$ & $\begin{array}{l}\text { Set germination } \\
(\%)^{z}\end{array}$ & $\begin{array}{l}\text { Foliage } \\
\text { vigor }^{\mathrm{y}}\end{array}$ & $\begin{array}{l}\text { Set germination } \\
(\%)^{z}\end{array}$ & $\begin{array}{l}\text { Foliage } \\
\text { vigor }^{\mathrm{y}}\end{array}$ & $\begin{array}{l}\text { Set germination } \\
(\%)^{z}\end{array}$ & $\begin{array}{l}\text { Foliage } \\
\text { vigor }^{\mathrm{y}}\end{array}$ \\
\hline 46 & 10 & $90.0 \mathrm{a}^{\mathrm{x}}$ & $4.00 \mathrm{a}$ & $92.5 \mathrm{a}$ & $4.00 \mathrm{a}$ & $100 \mathrm{a}$ & $4.00 \mathrm{a}$ & $97.5 \mathrm{a}$ & $4.00 \mathrm{a}$ \\
\hline 46 & 20 & $95.0 \mathrm{a}$ & $4.00 \mathrm{a}$ & $100 \mathrm{a}$ & $4.00 \mathrm{a}$ & $100 \mathrm{a}$ & $4.00 \mathrm{a}$ & $97.5 \mathrm{a}$ & $4.00 \mathrm{a}$ \\
\hline 46 & 30 & $90.0 \mathrm{a}$ & $4.00 \mathrm{a}$ & $82.5 \mathrm{a}$ & $3.75 \mathrm{a}$ & $97.5 \mathrm{a}$ & $4.00 \mathrm{a}$ & $95.0 \mathrm{a}$ & $4.00 \mathrm{a}$ \\
\hline 47 & 10 & $92.5 \mathrm{a}$ & $3.75 \mathrm{a}$ & $90.0 \mathrm{a}$ & $4.00 \mathrm{a}$ & $95.0 \mathrm{a}$ & $4.00 \mathrm{a}$ & $95.0 \mathrm{a}$ & $4.00 \mathrm{a}$ \\
\hline 47 & 20 & $87.5 \mathrm{a}$ & $4.00 \mathrm{a}$ & $92.5 \mathrm{a}$ & $4.00 \mathrm{a}$ & $95.0 \mathrm{a}$ & $4.00 \mathrm{a}$ & $97.5 \mathrm{a}$ & $4.00 \mathrm{a}$ \\
\hline 47 & 30 & $92.5 \mathrm{a}$ & $4.00 \mathrm{a}$ & $77.5 \mathrm{a}$ & $3.50 \mathrm{a}$ & $95.0 \mathrm{a}$ & $4.00 \mathrm{a}$ & $95.0 \mathrm{a}$ & $4.00 \mathrm{a}$ \\
\hline 48 & 10 & $85.0 \mathrm{a}$ & $3.25 \mathrm{~b}$ & $85.0 \mathrm{a}$ & $3.75 \mathrm{a}$ & $97.5 \mathrm{a}$ & $4.00 \mathrm{a}$ & $90.0 \mathrm{ab}$ & $3.75 \mathrm{a}$ \\
\hline 48 & 20 & $62.5 \mathrm{~b}$ & $3.00 \mathrm{~b}$ & $77.5 \mathrm{a}$ & $2.75 \mathrm{~b}$ & $100 \mathrm{a}$ & $3.50 \mathrm{bc}$ & $75.0 \mathrm{bc}$ & $3.25 \mathrm{~b}$ \\
\hline 48 & 30 & $45.0 \mathrm{c}$ & $3.00 \mathrm{~b}$ & $50.0 \mathrm{~b}$ & $2.50 \mathrm{~b}$ & $82.5 \mathrm{~b}$ & $3.25 \mathrm{c}$ & $65.0 \mathrm{c}$ & $3.00 \mathrm{~b}$ \\
\hline Untreated control & & $92.5 \mathrm{a}$ & $3.00 \mathrm{~b}$ & $87.5 \mathrm{a}$ & $3.30 \mathrm{a}$ & $82.5 \mathrm{~b}$ & $3.25 \mathrm{c}$ & $100 \mathrm{a}$ & $4.00 \mathrm{a}$ \\
\hline $\operatorname{LSD}_{(P=0.05)}$ & & 16.3 & 0.36 & 27.5 & 0.61 & 10.5 & 0.49 & 15.5 & 0.337 \\
\hline
\end{tabular}

${ }^{\mathrm{z}}$ Set germination was assessed 12 weeks after planting sets. Each value represents the mean of 40 sets.

${ }^{\mathrm{y}}$ Vigor of foliage growth was assessed 12 weeks after planting sets. Foliage vigor was evaluated using a scale of 0 to 4,0 being no set germination (no plant growth) and 4 being the highest foliage vigor.

'Values followed by the same letter within each column are not significantly different according to Fisher's protected least significant difference (LSD).

Table 8. Set germination and vigor of foliage growth of horseradish plants in the field in Illinois and Wisconsin after set treatment in hot water in 2008 and 2009.

\begin{tabular}{|c|c|c|c|c|c|c|c|}
\hline \multirow[b]{2}{*}{ Location } & \multirow[b]{2}{*}{ Year } & \multirow[b]{2}{*}{ Cultivar } & \multirow[b]{2}{*}{ Treatment } & \multicolumn{2}{|c|}{ Set germination $(\%)^{z}$} & \multicolumn{2}{|c|}{ Foliage vigor $^{\mathrm{y}}$} \\
\hline & & & & 6 weeks $^{x}$ & 18 weeks $^{\mathrm{x}}$ & 6 weeks $^{x}$ & 18 weeks \\
\hline \multirow[t]{12}{*}{ Collinsville, IL } & 2008 & 1573 & Hot water $\left(47^{\circ} \mathrm{C}, 20 \mathrm{~min}\right)$ & 7.25 & $8.50 \mathrm{a}^{\mathrm{w}}$ & 3.00 & $4.00 \mathrm{a}$ \\
\hline & & & Untreated control & 7.25 & $7.75 b$ & 3.00 & $3.75 \mathrm{~b}$ \\
\hline & & & $\left.\operatorname{LSD}_{(P}=0.05\right)$ & NS & 0.50 & NS & 0.14 \\
\hline & & BTW & Hot-water $\left(47^{\circ} \mathrm{C}, 20 \mathrm{~min}\right)$ & $5.75 \mathrm{~b}$ & $6.25 \mathrm{~b}$ & $3.50 \mathrm{a}$ & $3.75 \mathrm{a}$ \\
\hline & & & Untreated control & $8.00 \mathrm{a}$ & $8.00 \mathrm{a}$ & $3.00 \mathrm{~b}$ & $3.50 \mathrm{~b}$ \\
\hline & & & $\left.\operatorname{LSD}_{(P}=0.05\right)$ & 0.72 & 0.76 & 0.16 & 0.21 \\
\hline & 2009 & 1573 & Hot water $\left(47^{\circ} \mathrm{C}, 20 \mathrm{~min}\right)$ & $8.00 \mathrm{a}$ & $8.50 \mathrm{a}$ & $2.75 \mathrm{a}$ & 4.00 \\
\hline & & & Untreated control & $6.00 \mathrm{~b}$ & $7.00 \mathrm{~b}$ & $2.00 \mathrm{~b}$ & 4.00 \\
\hline & & & $\left.\operatorname{LSD}_{(P}=0.05\right)$ & 0.92 & 0.89 & 0.41 & NS \\
\hline & & BTW & Hot water $\left(47^{\circ} \mathrm{C}, 20 \mathrm{~min}\right)$ & 9.00 & 9.00 & $2.75 \mathrm{~b}$ & 4.00 \\
\hline & & & Untreated control & 9.50 & 9.50 & $3.50 \mathrm{a}$ & 4.00 \\
\hline & & & $\left.\operatorname{LSD}_{(P}=0.05\right)$ & NS & NS & 0.21 & NS \\
\hline \multirow[t]{3}{*}{ Eau Claire, WI } & $2008+2009$ & BTW & Hot water $\left(47^{\circ} \mathrm{C}, 20 \mathrm{~min}\right)$ & 8.63 & 9.00 & 3.25 & 4.00 \\
\hline & & & Untreated control & 9.25 & 9.75 & 3.50 & 4.00 \\
\hline & & & $\operatorname{LSD}_{(P=0.05)}$ & NS & NS & NS & NS \\
\hline
\end{tabular}

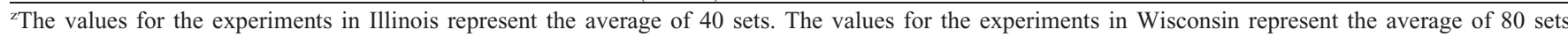
(representing two years, each year with 40 sets).

${ }^{y}$ Vigor of foliage growth was assessed on a scale of 0 to 4 in each plot, 0 being no set germination (no plant growth) and 4 being the highest foliage vigor.

${ }^{\mathrm{x}}$ Weeks after planting sets.

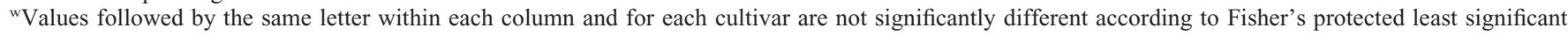
difference (LSD).

NS $=$ nonsignificant. 
design with four replications (10 sets per replication). The space between adjacent sets within the row was $60 \mathrm{~cm}$ and the space between the adjacent rows was $90 \mathrm{~cm}$. In 2008 , sets of cultivar BTW were planted on 24 May. Set germination and foliage vigor were recorded on 5 July and 26 Sept. Plants were harvest on 26 Sept. and roots were assessed for severity of internal discoloration. In 2009, sets were planted on 4 June. Set germination and foliage vigor were evaluated on 18 July and 9 Oct. Plants were harvested on 9 Oct. and roots were assessed for severity of internal discoloration.

Data analysis. The data on sets with fungal colonies, root infection, set germination, and foliage vigor were analyzed using SAS procedures (SAS Institute, Cary, NC). The data were subjected to analysis of variance without any transformation. Mean values of the data were compared using Fisher's protected least significant difference at $P=0.05$.

\section{Results}

Set culturing. The percentage of the sets with fungal colonies decreased as the treatment temperature was raised and duration of treatment increased. In the experiment with cultivar 1590, percentages of the sets with fungal colonies were significantly lower in all treatments at 44 to $50{ }^{\circ} \mathrm{C}$ when compared with that of untreated sets (Table 1). In cultivar 1573, percentages of sets with fungal colonies in treatments at $46{ }^{\circ} \mathrm{C}$ for 20 and 30 min, $47{ }^{\circ} \mathrm{C}$ for 20 and $30 \mathrm{~min}$, and all treatments at $48{ }^{\circ} \mathrm{C}$ were significantly lower than that of untreated sets (Table 2). In cultivar 1722, percentages of the sets with fungal colonies were significantly lower in all treatments at 46 to $48^{\circ} \mathrm{C}$ in comparison with that of untreated sets (Table 2).

In the experiment with cultivar Victor-7, most of the cultured segments from untreated sets were covered with actively growing bacterial colonies. Percentages of sets with fungal colonies were significantly lower in treatments at $47^{\circ} \mathrm{C}$ for 20 and $30 \mathrm{~min}, 48^{\circ} \mathrm{C}$ for 20 and $30 \mathrm{~min}$, and all treatments at $49^{\circ} \mathrm{C}$ when compared with that of untreated sets (Table 3). Overall, the analyses of data showed that there was no significant difference in percentage of treated sets with fungal colonies between sets with 0.5 to $1.5 \mathrm{~cm}$ and sets with 1.6 to $3.0 \mathrm{~cm}$ in diameter (data are not presented). Similarly, there was no significant difference in percentage of sets with fungal colonies when the sets were treated at $47^{\circ} \mathrm{C}$ or greater and cultured within 2 weeks and 3 months after hot water treatment.

Verticillium and Fusarium species were identified in the colonies that grew from untreated sets (both asymptomatic and symptomatic sets) and the sets treated at 44 and 45 ${ }^{\circ} \mathrm{C}$. The colonies that grew out of the sets treated at $46{ }^{\circ} \mathrm{C}$ or greater were identified to be Rhizoctonia, Aspergillus, and Penicillium species.

Root infection-greenhouse studies. The results of greenhouse experiment with cultivars 1573 and BTW showed that set treatment at $47{ }^{\circ} \mathrm{C}$ for $20 \mathrm{~min}$ significantly reduced incidence and severity of internal root discoloration of horseradish roots (Table 4). In cultivar 1573 , only $8.33 \%$ of hot water-treated sets gave rise to internally discolored roots with a maximum discoloration severity of $5 \%$. In contrast, $83.33 \%$ of the plants grown from untreated sets had internally discolored roots with discoloration severity of up to $40 \%$. In cultivar BTW, none of the hot water-treated sets gave rise to a plant with discolored root, whereas $66.67 \%$ of the plants from untreated sets had internally discolored roots with up to $15 \%$ discoloration severity.

The results of the experiment with cultivars Czechoslovakia and Eastern in the greenhouse are presented in Table 5. None of the plants grown from asymptomatic sets that were treated in water at $47^{\circ} \mathrm{C}$ for $20 \mathrm{~min}$ had discolored roots. In comparison, roots of $25 \%$ and $12.5 \%$ of plants grown from untreated, asymptomatic sets of cultivars Czechoslovakia and Eastern, respectively, had discolored roots. In cultivar Czechoslovakia, less $13 \%$ of the plants grown from symptomatic sets treated in hot water had internally discolored roots, whereas $62.5 \%$ to $100 \%$ of the untreated, symptomatic sets gave rise to internally discolored roots (Table 5). In cultivar Eastern, none of the hot watertreated sets with $50 \%$ or less internal discoloration severity gave rise to plants with internally discolored roots. Also, only $12.5 \%$ of plants grown from hot water-treated sets with greater than $50 \%$ internal discoloration severity gave rise to discolored roots. In comparison, up to $75 \%$ of the plants grown from untreated sets gave rise to plants with internally discolored roots (Table 5).

Set germination and plant vigorgreenhouse study. In the greenhouse study with cultivars $15 \mathrm{~K}$ and 1573 , percentage of set germination and foliage vigor and weight in hot water treatments at $46,47,48$, and 49 ${ }^{\circ} \mathrm{C}$ and $50{ }^{\circ} \mathrm{C}$ for 10 and $20 \mathrm{~min}$, respectively, were not negatively affected when compared with those of the untreated sets (Table 6). The treatment at $50{ }^{\circ} \mathrm{C}$ for $30 \mathrm{~min}$, however, significantly reduced percentage of sets germination in both cultivars. In some hot water treatments, foliage vigor and/or foliage weight were significantly higher than those of untreated checks.

Set germination and plant vigor-field studies. In the field experiment in 2007, percentage of set germination and foliage vigor were negatively affected when the sets were treated at $48^{\circ} \mathrm{C}$ for either $20 \mathrm{~min}$ or for $30 \mathrm{~min}$ (Table 7). In cultivars $15 \mathrm{~K}, 1573$, and BTW, there were no significant differences in percentage of set germination and foliage vigor between the hot water treatments at 46,47 , and $48{ }^{\circ} \mathrm{C}$ for $10 \mathrm{~min}$ and those of untreated sets. In cultivar 1722, however, set germination and foliage vigor in hot water treatments at 46,47 , and $48{ }^{\circ} \mathrm{C}$ for $10 \mathrm{~min}$ were significantly higher than those of untreated sets (Table 7).

The results of the field experiments in Illinois and Wisconsin in 2008 and 2009 are presented in Table 8 . As a result of significant difference between the experiments in 2008 and 2009 in Illinois, the results of these experiments are presented separately. Percentage of set germination in hot water treatments was significantly lower than that of untreated sets only in cultivar BTW in 2009. Also in cultivar BTW in 2009, foliage vigor in hot water treatment was significantly lower than that of untreated sets 6 weeks after planting sets; however, there was no significant difference in foliage vigor between hot water-treated and untreated sets 18 weeks after planting sets. In cultivar 1573, percentage of set germination and foliage vigor in hot water treatment were either significantly higher than those of untreated sets or there were no significant differences in percentage of set germination and foliage vigor between hot water-treated sets and untreated sets (Table 8).

There were no significant differences between the experiments in 2008 and 2009 in Wisconsin; thus, the results were combined (Table 8). Also, there were no significant differences in percentage of set germination and foliage vigor between hot water-treated sets and untreated sets.

\section{Discussion}

The results of this study showed that setborne pathogens causing internal discoloration of horseradish roots can be effectively controlled by hot water treatment. Preparation of pathogen-free horseradish sets by hot water treatment is a simple, safe, reliable, and cost-effective method. Hot water treatment of horseradish sets is a simple practice because it can be achieved by using simple equipments/tools that are readily available everywhere and no license will be required for carrying out the protocol. The method is safe to people and the environment because no chemical is used for the set treatment. It is a reliable method because it controls pathogens carried in the sets, has no adverse effect on set germination or plant vigor at the effective temperature-time for control of the pathogens, and no resistance development in pathogens to treatment is expected. The method is cost-effective because the costs for implementation of the suggested hot water treatment are $\approx \$ 100$ per hectare, which is less than $1.5 \%$ farm-gate value of the crop (Babadoost, 2006). Hot water treatment of horseradish sets developed in this study is similar to hot water treatments of seeds and nursery root stocks reported by other investigators (Herder and Turechek, 2006; Lear and Lider, 1959; Nega et al., 2003; Walker, 1923; Wilson, 1974) that have been used for more than 80 years.

The results of this study indicated that temperatures below $46{ }^{\circ} \mathrm{C}$ do not effectively control Verticillium and Fusarium spp. in horseradish sets. Temperatures higher than $48{ }^{\circ} \mathrm{C}$ negatively affect set germination and/ or plant vigor of horseradish. The optimum treatment of horseradish sets to control pathogens without adverse effect on set germination and plant vigor is treatment in water with 
a temperature of $47^{\circ} \mathrm{C}$ for $20 \mathrm{~min}$. Treatment of horseradish sets in hot water at $47^{\circ} \mathrm{C}$ for 30 min is also effective for control of the setborne pathogens without significant effect on set germination or plant vigor. Thus, hot water treatment of horseradish sets for management of internal discoloration of roots is feasible.

In a preliminary experiment, Trierweiler et al. (2006) tried hot water treatment of horseradish sets and reported that only $7.8 \%$ of the plants grown from sets treated in hot water at $46{ }^{\circ} \mathrm{C}$ for $10 \mathrm{~min}$ exhibited a weak internal root discoloration, whereas $45.1 \%$ of untreated sets gave rise to plants with internally discolored roots. The findings in our study agree with the report by Trierweiler et al. (2006) that treatment of horseradish set in hot water at $46{ }^{\circ} \mathrm{C}$ for $10 \mathrm{~min}$ could eradicate/reduce set-borne inoculum of the pathogens causing internal discoloration of horseradish root. However, the results of our study showed that treatment of the sets hot water at $47{ }^{\circ} \mathrm{C}$ for 20 is more effective than treatment at $46{ }^{\circ} \mathrm{C}$ for $10 \mathrm{~min}$ and controls set-borne inoculum of Verticillium and Fusarium without any adverse effect on set germination or plant vigor.

Most of the fungal colonies that grew out of untreated, asymptomatic sets were Verticillium and Fusarium spp., the causal agents of the internal discoloration of horseradish roots. No Verticillium or Fusarium colonies were detected in the asymptomatic sets treated at $46{ }^{\circ} \mathrm{C}$ or greater in this study. The detected colonies in sets treated at $46{ }^{\circ} \mathrm{C}$ or greater were identified as Rhizoctonia, Aspergillus, and Penicillium spp., which are not considered vascular pathogens. These fungi are believed to be secondary invaders of horseradish roots. Rhizoctonia, Aspergillus, and Penicillium spp. are apparently tolerant to temperatures of 46 to $50{ }^{\circ} \mathrm{C}$.

In greenhouse studies, no internal root discoloration was observed in the plants grown from asymptomatic sets treated in water at $47^{\circ} \mathrm{C}$ for $20 \mathrm{~min}$. Also, treatment of internally discolored sets of cultivars Czechoslovakia and Eastern in hot water at $47{ }^{\circ} \mathrm{C}$ for $20 \mathrm{~min}$ resulted in only $12.5 \%$ or less of the plants with $5 \%$ or less discoloration severity compared with up to $100 \%$ of the plants with discolored roots (up to $40 \%$ discoloration severity) grown from untreated sets. This indicates that even if the producers mistakenly plant some sets with internal discoloration, the probability of having plants with discolored roots after set treatment in hot water at $47^{\circ} \mathrm{C}$ for $20 \mathrm{~min}$ is very low (less than $12.5 \%$ ).

Among all greenhouse and field studies conducted during this investigation, only the treatment of BTW in Illinois in 2008, sets treatment in hot water at $47{ }^{\circ} \mathrm{C}$ for $20 \mathrm{~min}$ resulted in slightly lower percentage of set germination that that of untreated sets. The lower percentage of set germination in cultivar BTW in this experiment could be the result of the temperature of water being higher than $47^{\circ} \mathrm{C}$. The same treatment with the same cultivar in 2009 in Illinois and in 2008 and 2009 in Wisconsin did not reduce percentage of set germination.

Treatment of horseradish sets in hot water at $47{ }^{\circ} \mathrm{C}$ for $20 \mathrm{~min}$ often resulted in higher percentages of set germination and higher foliage vigor in the greenhouse and fields. This could be the result of elimination of organisms associated with sets that are harmful to germination of sets or growth of the plants. Further investigations are needed to clarify the effects of hot water treatment of horseradish sets on improving set germination and plant growth.

\section{Literature Cited}

Aitken-Christie, J., T. Kozai, and M.A.L. Smith 1995. Automation and environmental control in plant tissue culture. Kluwer Academic Publishers, Dordrecht, The Netherlands.

Atibalentja, N. and D.M. Eastburn. 1996. Evaluation of inoculation methods for screening horseradish cultivars for resistance to Verticillium dahliae. Plant Dis. 81:355-363.

Babadoost, M. 2006. Development of internal discoloration of horseradish root in commercial fields, p. 5-6. In: Horseradish Res. Rev. \& Proc. Horseradish Growers School, Univ. Ill. Extension.

Babadoost, M., W. Chen, A.D. Bratsch, and C.E. Eastman. 2004. Verticillium longisporun and Fusarium solani: Two new species in the complex of internal discoloration of horseradish roots. Plant Pathol. 53:669-676.

Babadoost, M., W. Chen, A.D. Bratsch, and C.L. Wright. 2001. Incidence of horseradish diseases in Illinois; a detailed field survey, 2000, p. 9-13. In: Horseradish Res. Rev. \& Proc. Horseradish Growers School, Univ. Ill. Extension.

Babadoost, M. and S.Z. Islam. 2002. Effect of selected fungicides and biocontrol agents on the incidence of internal discoloration of horseradish root. Phytopathology 92(suppl):S5.

Boning, K. 1938. Die wichtigsten krankheiten und schadlinge des meerrettichs [The most important diseases and pests of horseradish]. Rev. Appl. Mycol. 18:365.

Courter, J.W. and A.M. Rhodes. 1969. Historical notes on horseradish. Econ. Bot. 23:156-164.

Eastburn, D.M. and R.J. Chang. 1994. Verticillium dahliae: A causal agent of root discoloration of horseradish in Illinois. Plant Dis. 78:496-498.

Gerber, J.M., C.C. Doll, R.K. Simons, and K.E. Fillingim. 1983. Internal discoloration of horseradish-Development of symptoms. Univ. Illinois Veg. Res. Rep. \& Hort. Serv. 47:34-37.

Heald, F.D., L.K. Jonesk, and G.A. Huber. 1937. Plant disease surveys. Washington Agric. Exp. Sta. Bull. 354.
Herder, K. and W. Turechek. 2006. Evaluating hotwater treatment as means for eradicating Xanthomonas fragariae in strawberry nursery stock. Phytopathology 96(suppl):S47.

Jensen, J.L. 1888. The propagation and prevention of smut in oats and barley. J. Royal Agric. Soc. England 24:397-415.

Kadow, K.J. and H.W. Anderson. 1940. A study of horseradish diseases and their control. Univ. Illinois Agr. Exp. Sta. Bull. 469:529-583.

Lear, B. and L.A. Lider. 1959. Eradication of rootknot nematodes from grapevine rootings by hot water. Plant Dis. Rpt. 43:314-317.

McGee, D.C. 1995. Advances in seed treatment technology. Asian Seed 95, New Delhi, India, 27-29 Sept. 1995.

Meyer, M.M. and G.M. Milbrath. 1977. In vitro propagation of horseradish with leaf pieces. HortScience 12:544-545.

Mueller, J.P., J.A. Percich, and J.E. Mitchell. 1982. Root deterioration associated with Verticillium wilt of horseradish. Plant Dis. 66:410-414.

Nega, E., R. Ulrich, S. Werner, and M. John. 2003. Hot water treatment of vegetable seed-An alternative seed treatment method to control seed borne pathogens in organic farming. J. Plant Dis. Prot. 110:220-234.

Neri, F., M. Mari, S. Brigati, and P. Bertolini. 2009. Control of Neofabraea alba by plant volatile compounds and hot water. Postharvest Biol. Technol. 51:425-430.

Norton, M., M. Uchanski, K. Scoggins, and R.M. Skirvin. 2001. Tissue culture project progress. 2006, p. 18-20. In: Horseradish Res. Rev. \& Proc. Horseradish Growers School, Univ. Ill. Extension.

Percich, J.A. and D.R. Johnson. 1990. A root rot complex of horseradish. Plant Dis. 74:391-393.

Potschke, A. 1923. On the black discoloration of horseradish. Biologischen Reichsanstalt für Land und Forstwirtschaft 11:337-338.

Rhodes, A.M. 1977. Horseradish-Problems and research in Illinois, p. 137-147. In: Seigler, D.S. (ed.). Crop resources. Academic Press, New York, NY.

Stark, C. 1961. Das Auftreten der VerticilliumTracheomykosen in Hamburger Gartenbaukulturen. Gartenbauwissenchaft 26:493-528.

Trierweiler, B., H. Schirmer, V. Gräf, and B. Tauscher. 2006. Hot water treatment-A possible method to reduce Verticillium infection of horseradish (black discoloration). International Symposium on Vegetable Safety and Human Health. Beijing, China, 21-23 Aug. 2006. Abstracts.

Uchanski, M., M.A. Norton, and R.M. Skirvin. 2007. The logistics and economics of producing pathogen-free (PF), tissue culture derived horseradish sets, p. 14-19. In: Horseradish Res. Rev. \& Proc. Horseradish Growers School, Univ. Ill. Extension.

Uchanski, M., R.M. Skirvin, and M.A. Norton. 2004. The use of in vitro thermo-therapy to obtain Turnip mosaic virus-free horseradish plants. Acta Hort. 631:175-179.

Walker, J.C. 1923. The hot water treatment of cabbage seed. Phytopathology 13:251-253.

Wilson, G.J. 1974. Control of celery leaf spot. New Zealand Agr. 129:33-35. 